\title{
Etiopathogenesis of midfacial fractures in patients treated at Maxillofacial Surgery Clinic, Medical University of Lublin in 2007-2011
}

\author{
Jolanta Wojciechowicz, Bartosz Samczyk, Tomasz Tomaszewski, Marcin Baran \\ Maxillofacial Surgery Clinic, Medical University of Lublin, Poland \\ Wojciechowicz J, Samczyk B, Tomaszewski T, Baran M. Etiopathogenesis of midfacial fractures in patients treated at Maxillofacial Surgery \\ Clinic, Medical University of Lublin in 2007-2011. J Pre-Clin Clin Res. 2013; 7(1): 43-47.
}

\begin{abstract}
Introduction: With the growing industrialization and the increasingly rapid pace of life the number and variety of injuries are growing higher. In the midst of injuries, the midfacial injuries constitute a considerable part and pose a huge therapeutic challenge. The presence of life sustaining organs in the area of midfacial injuries require use of modern surgical and diagnostic methods and practices implemented by multi-specialty operative teams.

Objective: The purpose of the work is the analysis of clinical documentation of patients who had been treated in 2007 - 2011 at Maxillofacial Surgery Clinic, Medical University of Lublin due to midfacial injury.

Materials and Method: A subject of the analysis is a group of 424 patients examined at Maxillofacial Surgery Clinic, Medical University of Lublin in the years 2007-2011 due to midfacial injury. Medical documentation in the form of case history and radiological images were analyzed and reported in a special form of Microsoft Excel Program. Wanyjura's classification of fracture was used in the study. The most common reasons of midfacial fractures are batteries and traffic accidents. Men aged 20 to 40 years old prevailed among all patients. The number of surgically treated patients was growing in the recent years and it accounted for $75.2 \%$. Indications for surgical treatment were visual, aestetics and stomatognatic disturbances.

Conclusions: In the recent years, an increase in midfacial fractures may be discerned among other types of fractures of maxillofacial area. Thorough radiologic analysis of injuries using up-to-date research methods allows to establish the most efficient method of therapeutical conduct. An appropriate education, observance of traffic as well as health and safety regulations allows to decrease the number and causes of midfacial injuries.
\end{abstract}

\section{Key words}

maxillofacial fractures, osteosynthesis, treatment, epidemiology

\section{INTRODUCTION}

With the growing industrialization and the increasingly rapid pace of life the number and variety of injuries are growing higher. In the midst of injuries, the midfacial injuries constitute a considerable part and pose a huge therapeutic challenge. The presence of life sustaining organs in the area of midfacial injuries as well as aesthetics require use of modern surgical and diagnostic methods and practices implemented by multi-specialty operative teams. A thorough knowledge of anatomic structures of the maxillofacial area as well as dental anatomy and schemes of fracture classification of this area allow to choose the optimal method of treatment [1]. General condition of the patient, kind of fracture, dislocation of a bone fractions, the time lapse since the injury, soft tissue lesions, and general condition of a patient should be taken into account while choosing the method of treatment. Therapeutic procedure encompasses fracture correction, bone fractures immobilization and elimination accompanying complications taking into consideration facial aesthetics and functioning of sensory organs. Despite significant improvement and spread of surgery methods, orthopedic and surgical-orthopedic methods are commonly used to treat fractures. Application of mini and microplate

Address for correspondence: Jolanta Wojciechowicz, Wyżynna 17/46, 20-560 Lublin, Poland

e-mail: lanyfztk@wp.pl

Received: 15 March 2013; accepted: 19 June 2013 osteosynthesis and bioabsorbable materials, endoscopic techniques and stereolithography methods in reproductive procedures treating bone voids [2].

Objective: The purpose of the work is the analysis of clinical documentation of patients who had been treated in 20072011 at Maxillofacial Surgery Clinic, Medical University of Lublin due to midfacial injury.

\section{MATERIALS AND METHOD}

A subject of the analysis is a group of 424 patients examined at Maxillofacial Surgery Clinic, Medical University of Lublin in the years 2007-2011 due to midfacial injury. Medical documentation in the form of case history and radiological images were analyzed and reported in a special form of Microsoft Excel Program. Wanyjura's classification of fracture was used in the study.

\section{RESULTS}

The obtained results were statistically analyzed. The acquired measurable parameters were presented by means of the average value and standard deviation, mediana, whereas, the non-measurable values by means of multiplicity and interest. 
The Mann Whitney's test was used in order to compare two independent groups, whereas, the Kruskal-Wallis's test for more numerous groups. Evenness test $\mathrm{Ch}^{2}$ was used to examine the correlation among the examined patients. Pertinence level $p<0.05$ indicating the presence of significant statistical differences or dependences was adopted. Data base and statistical research were carried out by means of computer software STATISTICA 10.0 (StatSoft, Poland).

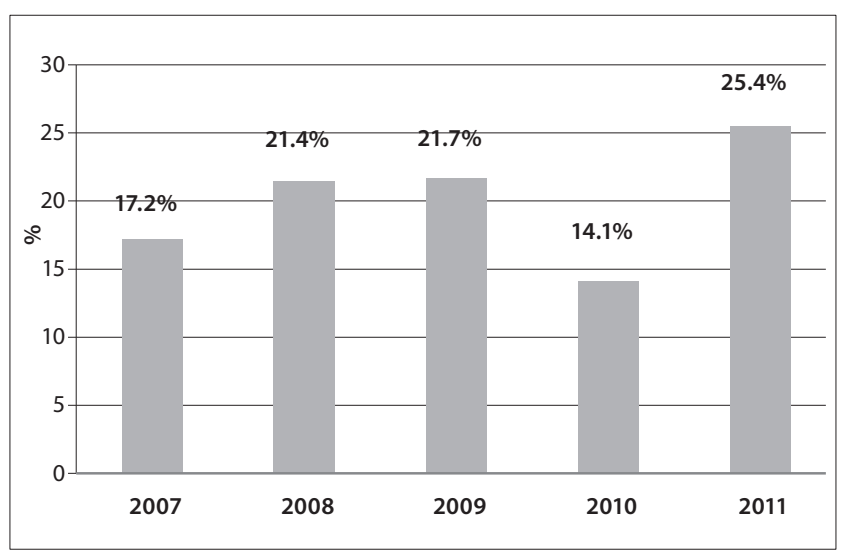

Figure 1. Percentage of fractures in the years 2007-2011

Among 424 patients with midfacial fractures who were hospitalized at Maxillofacial Surgery Clinic, Medical University of Lublin in the years 2007-2011, the highest number of such fractures occurred in 2011 (25.4\%) in comparison with the years 2007-2011 (Fig. 1).

Researches demonstrate that the most frequent causes of fractures were batteries (45.2\%) and transportation accidents (20.5\%), whereas, accidental falls accounted for $15.3 \%$, jobrelated accidents (13.2\%) and sport accidents (5.6\%), (Fig. 2).

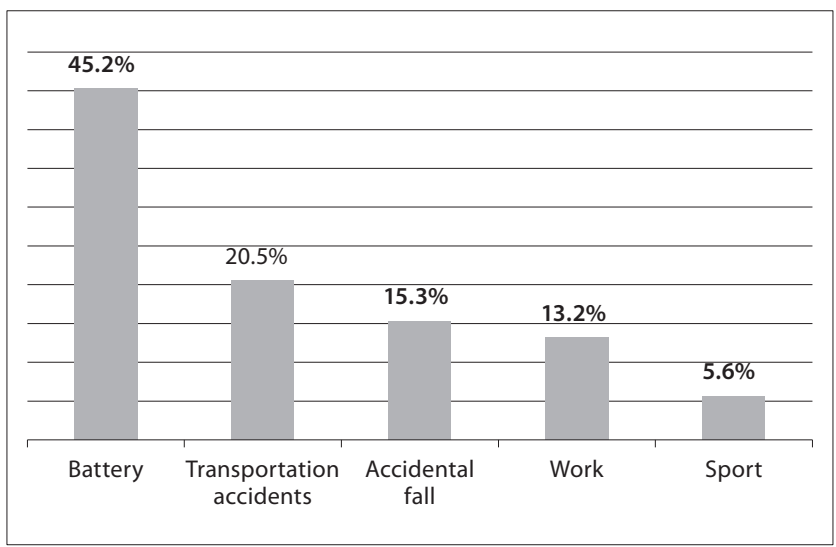

Figure 2. The percentage of hospitalized patients considering the cause of fractures

A statistical analysis showed that fractures due to battery more frequently occurred among men (48.5\%) in comparison with women (19.1\%). The statistical analysis showed a significant relation between the cause of fracture and sex, $(\mathrm{p}=0.0002)$, (Tab. 1).

Women prevailed in the group of patients hospitalized due to transportation accidents (36.1\%) and accidental falls. The reminder of causes accounts especially for batteries where the dominant group were men (48.5\%), (Fig 3).

A statistical analysis revealed a significant relation between the age and a cause of fracture, ( $\mathrm{p}=0.00001)$, (Tab. 2).
Table 1. A cause of fracture taking into consideration patient's sex

\begin{tabular}{lrrrr}
\hline A cause of fracture & \multicolumn{2}{c}{ Women } & \multicolumn{2}{c}{ Men } \\
\cline { 2 - 5 } & $\mathrm{n}$ & $\%$ & $\mathrm{~N}$ & $\%$ \\
\hline Battery & 9 & 19.1 & 183 & 48.5 \\
\hline Accident & 17 & 36.1 & 70 & 18.5 \\
\hline Sport & 2 & 4.2 & 22 & 5.8 \\
\hline Fall & 14 & 29.7 & 51 & 13.5 \\
\hline Work & 5 & 10.6 & 51 & 13.5 \\
\hline Total & 47 & 100.0 & 377 & 100.0 \\
\hline Stisticl
\end{tabular}

Statistical analysis: $\mathrm{Chi}^{2}=21.94 ; \mathrm{p}=0.0002^{*}$

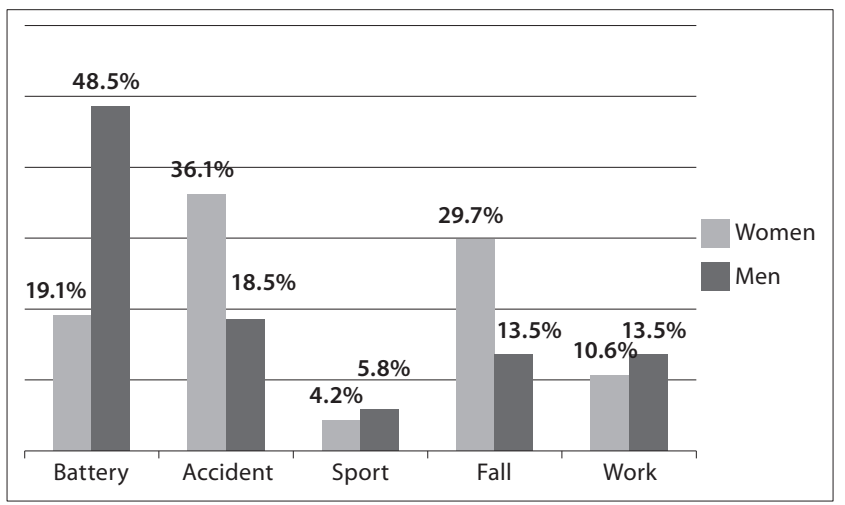

Figure 3. Percentage of examined accounting for the cause of fracture in the group of women and men

Table 2. A cause of fracture considering age

\begin{tabular}{|c|c|c|c|c|c|c|c|c|c|c|c|}
\hline \multirow{2}{*}{$\begin{array}{l}\text { A } \\
\text { cause } \\
\text { of frac- } \\
\text { ture }\end{array}$} & \multicolumn{2}{|c|}{$\begin{array}{l}\text { Up to } 20 \\
\text { years old }\end{array}$} & \multicolumn{2}{|c|}{$\begin{array}{c}21-30 \text { years } \\
\text { old }\end{array}$} & \multicolumn{2}{|c|}{$\begin{array}{c}31-40 \\
\text { years old }\end{array}$} & \multicolumn{2}{|c|}{$\begin{array}{c}41-50 \\
\text { years old }\end{array}$} & \multicolumn{2}{|c|}{$\begin{array}{l}\text { Over } 50 \\
\text { years old }\end{array}$} & \multirow{2}{*}{$\begin{array}{c}\text { Aver- } \\
\text { age }\end{array}$} \\
\hline & $\mathrm{n}$ & $\%$ & $\mathrm{~N}$ & $\%$ & $n$ & $\%$ & $\mathrm{~N}$ & $\%$ & $\mathrm{n}$ & $\%$ & \\
\hline Battery & 34 & 44.7 & 71 & 54.2 & 34 & 47.2 & 30 & 44.1 & 23 & 29.8 & 32.4 \\
\hline $\begin{array}{l}\text { Trans- } \\
\text { port- } \\
\text { ation } \\
\text { acci- } \\
\text { dent }\end{array}$ & 21 & 27.6 & 26 & 19.8 & 16 & 22.2 & 9 & 13.2 & 15 & 19.4 & 32.2 \\
\hline Sport & 9 & 11.8 & 9 & 6.8 & 5 & 6.9 & 1 & 1.4 & 0 & 0 & 23.1 \\
\hline $\begin{array}{l}\text { Acci- } \\
\text { dental } \\
\text { fall }\end{array}$ & 8 & 10.5 & 16 & 12.2 & 6 & 8.3 & 17 & 25.0 & 18 & 23.3 & 40.1 \\
\hline Work & 4 & 5.2 & 9 & 6.8 & 11 & 15.2 & 11 & 16.1 & 21 & 27.2 & 43.7 \\
\hline Total & 76 & 100.0 & 131 & 100.0 & 72 & 100.0 & 68 & 100.0 & 77 & 100.0 & \\
\hline
\end{tabular}

Batteries being a cause of fracture prevail in the age group of 21-30 year-olds (54.2\%), transportation accidents commonly occur in patients up to 20 years old (27.6\%), sport accidents (11.8\%), job-related accidents mainly concern the group over 50 years old (27.2\%), (Tab. 2).

Countryside residents prevail among patients treated due to fractured caused as a result of job-related accidents (24.8\%) and transportation accidents (23.8\%), whereas, town residents prevail among victims of batteries (52.7\%), accidental falls and sport accidents (Fig. 4).

Classification of fractures according to $\mathrm{H}$. Wanyury from 1991 was used in the analysis (12). Midface fractures of Maxillo-Zygomatic Complex Fracture (MZCF) type 


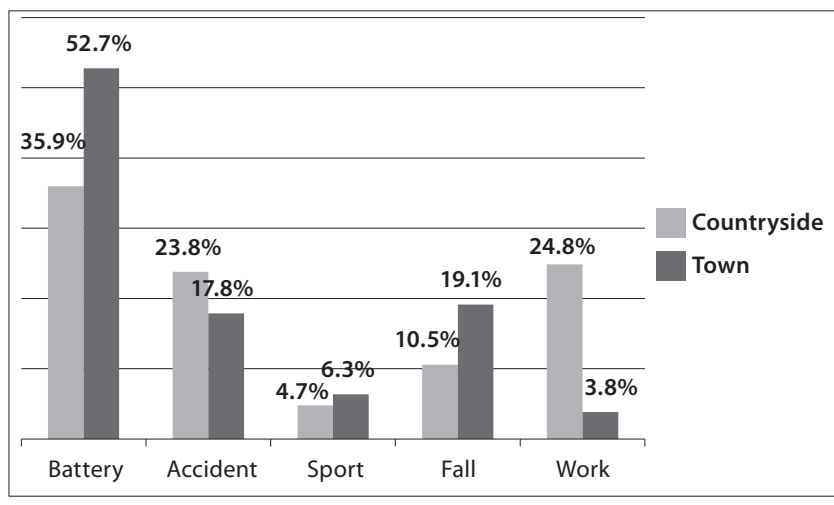

Figure 4. Percentage of examined considering the cause of fracture in a group of patients residing in a town and the countryside

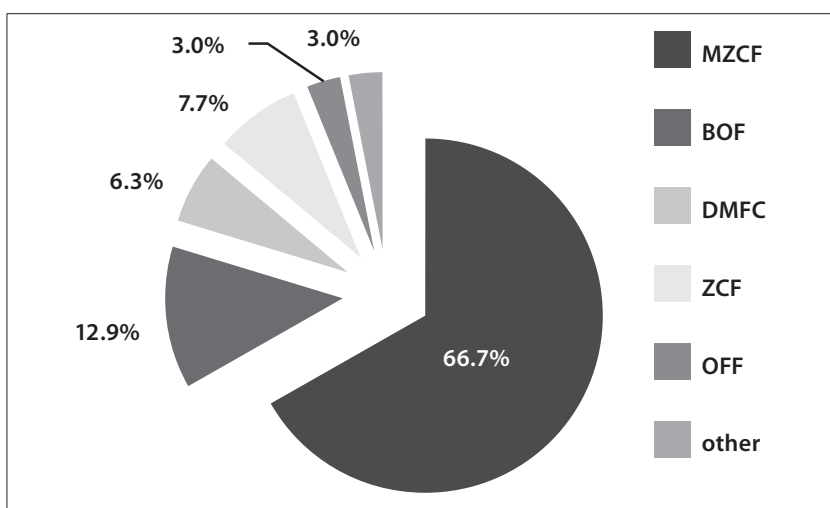

Figure 5. Percentage of examined taking into account a type of fracture. MZCF - Maxillo-Zygomatic Complex Fracture; ZCF - Zygomatic Complex Fracture; OFF - Orbitofrontal Fracture; BOF - Blow-out Fracture; DMFC - Disslocation of Maxillofacial Complex

occurred in $66.7 \%$ patients. Fractures Orbitofrontal Fracture (OFF) type (3.0\%) and DMFC type (6.3\%) account for the lowest percentage (Fig.5) Fractures of maxillofacial region may be treated applying three methods: surgical treatment - open reduction and osteosynthesis using the mini and micro plates, orthopedic - intermaxillary fixation, combined orthopedic and surgical treatment and other methods for example conservative treatment.

Table 3. Treatment methods

\begin{tabular}{lcc}
\hline Treatment methods & $\mathrm{n}$ & $\%$ \\
\hline Osteosynthesis & 305 & 71.9 \\
\hline Orthopedic & 86 & 20.2 \\
\hline Osteosynthesis and orthopedic treatment & 22 & 5.2 \\
\hline Other & 11 & 2.5 \\
\hline Total & 424 & 100.0 \\
\hline
\end{tabular}

Osteosynthesis was the most frequent treatment method used (71.9\%), whereas, $20.2 \%$ patients were treated orthopedically, in $5.2 \%$ patients orthopedic treatment and ostesythesis were applied and $2.5 \%$ of patients took advantage of other treatment methods (Tab. 3, Fig. 6).

Statistical analysis showed a significant relation between the cause of fracture and the treatment method ( $\mathrm{p}=0.003)$, (Tab. 4).

In the case of fractures being a result of batteries osteosynthesis $(77.6 \%)$ was the most common treatment method. Likewise in all other cases orthopedic treatment was the most frequently applied treating sport related injuries.

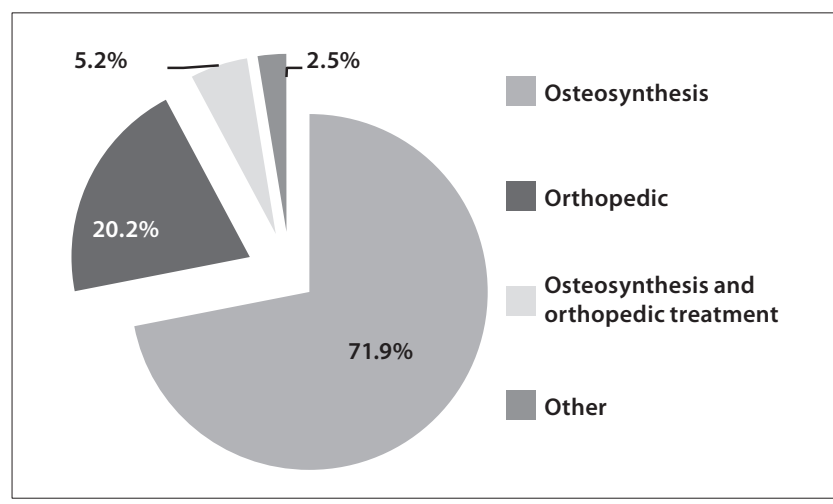

Figure 6. Percentage of examined accounting for treatment method

Table 4. Treatment method considering the cause of fracture

\begin{tabular}{lcccccccc}
\hline \multirow{2}{*}{$\begin{array}{l}\text { A cause of } \\
\text { fracture }\end{array}$} & \multicolumn{2}{c}{ Other } & \multicolumn{3}{c}{ Osteosynthesis } & \multicolumn{2}{c}{$\begin{array}{c}\text { Osteosynthesis } \\
+ \text { orthopedic }\end{array}$} & \multicolumn{2}{c}{ Orthopedic } \\
\cline { 2 - 10 } & $\mathrm{N}$ & $\%$ & $\mathrm{n}$ & $\%$ & $\mathrm{n}$ & $\%$ & $\mathrm{n}$ & $\%$ \\
\hline Battery & 5 & 2.6 & 149 & 77.6 & 6 & 3.1 & 32 & 16.6 \\
\hline Accident & 5 & 5.7 & 56 & 64.3 & 10 & 11.4 & 16 & 18.3 \\
\hline Sport & 0 & 0.0 & 21 & 87.5 & 0 & 0.0 & 3 & 12.5 \\
\hline Fall & 1 & 1.5 & 47 & 72.3 & 1 & 1.5 & 6 & 24.6 \\
\hline Work & 0 & 0.0 & 32 & 57.1 & 5 & 8.9 & 19 & 33.9 \\
\hline Statistical analysis: $\mathrm{Chi}^{2}=30.27 ; \mathrm{p}=0.003^{*}$ & & & & &
\end{tabular}

Mixed treatment methods were used in treatment of injuries caused by transportation related accidents (11.4\%).

The period of 7.5 days was an average time of reporting an injury. Statistical analysis showed that the longest reporting time concerned transportation and job-related accidents in comparsion with batteries, sport accidents and falls. The revealed differences were significantly statistical, $(\mathrm{p}<0.0001)$.

The average hospitalization time was 8.7 days. The longest hospitalization time was 23 days. The statistical analysis showed that hospitalization time among patients who were treated due to transportation and job-related accidents was significantly longer, in comparison with patients who were treated due to batteries, sport accidents and falls. The revealed differences were statistical ( $\mathrm{p}=0.02)$, (Tab. 5).

Table 5. Hospitalization time after injury considering the cause of fracture

\begin{tabular}{lccc}
\hline A causa of fracture & Mean & Standard deviation & Median \\
\hline Battery & 8.7 & 3.7 & 8.0 \\
\hline Accident & 9.4 & 4.0 & 9.0 \\
\hline Sport & 7.6 & 3.1 & 8.0 \\
\hline Fall & 8.0 & 4.1 & 8.0 \\
\hline Work & 9.3 & 3.6 & 9.0
\end{tabular}

Statistical analysis: $\mathrm{H}=12.32 ; \mathrm{p}=0.02$ *

The statistical analysis showed that patients treated using the orthopedical and osteosynthesis method were hospitalized significantly longer in comparison with patients treated using osteosynthesis, solely orthopedically or by the means of other method, $(\mathrm{p}<0.0001)$, (Tab. 6).

Among clinical symptoms examined in patients hospitalized due to midfacial fractures, asymmetry (57.7\%) was the most frequently cited, lower edge of orbital rim displacement (48.3\%) and other symtoms, (32.5\%), (Tab. 7). 
Table 6. Hospitalization and treatment period

\begin{tabular}{lccc}
\hline Treatment method & Mean & Standard deviation & Median \\
\hline Other & 7.6 & 4.5 & 6.5 \\
\hline Osteosynthesis & 9.2 & 3.3 & 9.0 \\
\hline Osteosynthesis and orthopedic treatment & 12.2 & 3.6 & 12.0 \\
\hline Ortophedic treatment & 6.5 & 4.3 & 5.0 \\
\hline
\end{tabular}

Statistical analysis: $\mathrm{H}=69.61 ; \mathrm{p}<0.0001^{*}$

Table 7. Other symptoms due to fracture

\begin{tabular}{lcc}
\hline Sympthoms & $\mathrm{n}$ & $\%$ \\
\hline Diplopia & 78 & 18.4 \\
\hline Malocclusion & 49 & 11.5 \\
\hline Asymmetry & 245 & 57.7 \\
\hline Orbital rim displacement & 205 & 48.3 \\
\hline Visual disturbance & 31 & 7.3 \\
\hline Other & 138 & 32.5 \\
\hline
\end{tabular}

Fractures were treated by the means of various surgical approaches which are listed in the table below. Intraoral approach $(67.6 \%)$ was the most common, followed by intraconjunctival approach $(8.0 \%)$ and at the same rate subciliary and through superciliary arch aproach, 3.5\% and $3.3 \%$ respectively (Tab. 8 ).

Table 8. Surgical approach

\begin{tabular}{lcc}
\hline Surgical approach & $\mathrm{N}$ & $\%$ \\
\hline Intraoral & 287 & 67.6 \\
\hline Lateral margin of orbit & 12 & 2.8 \\
\hline Infraorbital & 3 & 0.7 \\
\hline Intraconjunctival & 34 & 8.0 \\
\hline Subciliary & 15 & 3.5 \\
\hline Superciliary arch & 14 & 3.3 \\
\hline Other* & 105 & 24.7 \\
\hline
\end{tabular}

* in case of patients without any surgical approach used

\section{DISCUSSION}

In the years 2007-2011, 425 patients were hospitalized due to midface fracture at Clinic of Maxillofacial Surgery of Medical University in Lublin. Juxtaposing the data with other data concerning our clinic gathered in the years 19901999 , a slight growth in the number of such fraction may be discerned [3]. The same findings were stated also by other domestic and foreign works (authors) $[4,5,6,7,8]$. The male among all hospitalized, constantly constitute the greatest percentage from $2: 1$ to $6.6: 1$, especially in a group where maxillo-facial fractures were caused by batteries $(48.5 \%)[6,9$, $10,11]$. The lastly mentioned cause prevails over others and it is the reason for hospitalization due to midface fractures. Communication accidents constitute the second major cause of fractures (20.5\%). The statistics is confirmed by other domestic authors, however, in the case of upper facial fractures, batteries alike communication accidents are to most common cause of fractures.

D. Wanyura's analysis from 2006 concerning DMFC in hospitalised patients at Clinic of Maxillofacial Surgery in Warsaw, communicative accidents were the reason of $63.5 \%$ fractures, batteries constituted $14.8 \%$ [12], whereas, A. Szarmach in his publication concerning Maxillofacial fractures in 30-year period covering north-eastern region of Poland, quotes $53.3 \%$ of batteries and $19.3 \%$ of communication accidents [11]. Referring to foreign publications, the data is variable and depends on many socio-demographic factors and even geographic location of a given country. In connection with the lastly mentioned, analysis of injuries causes carried out on the basis of the research published by authors from various countries and continents. In Insbruck (Austria) so called ADL (Activities of daily life and play accidents) - 38\%, especially in winter months when skiing is practiced, is quoted on the first place among causes of injuries [4].

Whereas, at hospital in New Dehli (India) where are hospitalized many immigrants from various provinces, the poor, the unemployed, the abusing alcohol, the batteries are the main reason for hospitalization, however, up to this point, communication accidents prevailed [13]. An evidence for impact of socio- demographic factors on etiopathogenesis of injuries is also analysis of reasons of injuries in Nigeria which reflects the situation of the whole African continent.

Bicycle and motorbike accidents are the most common, the batteries, sport injuries and injuries caused by animals are the second most frequently cited [14].

Authors clarify that the poor infrastructurization, complete lack of knowledge, lack of traffic regulations among drivers and lack of permission to drive mechanic vehicles, and insufficient supervision on the police part. In well-developed countries such as Great Britain, communication accidents as a reason of injuries occurs in the same extend as batteries although it is attributed to overuse of alcohol by perpetrators, overspeeding, and non-observance of traffic regulations [7]. In Brazil, a group of people aged 21-30 constitutes the greatest number of post traumatic patient. In the group among the reasons of injuries prevailed communication accidents (bike and motorbikes accidents were the most frequent), batteries and shootings $[5,15]$.

Japanese scientists carried out an analysis of reasons of injuries among the elderly because the average life span in this area is the highest in the world (WHO). This age group is submitted to numerous statistical examinations, and the reasons of injuries are of slightly different nature because they are mainly random collapses and communication accidents [16].

In the area of Lublin province, statistical analysis revealed significant connection between age and reason of injuries. Batteries prevailed in the age group of 21-30 years, communication accidents in the group up to 20 years, vocational accidents concerned mainly group of people from rural areas over 50 years old.

It may be stated that it reflects the specific of the Lublin region because it is in great part an agricultural area and people in the productive age still take active part in agriculture works without caring for observance of occupational safety and health which caused increase in the amount of injuries in this age group [17]. In the upper maxillofacial fractures treatment further increase in number of cases which are surgically treated may be discerned.

In our analysis it constitutes 71.9\%, in the years 1990-1999 it was $61.3 \%$ of all cases.

Hospitalization period of patients treated by the means of surgical methods (9.2 days) or exclusively orthopedical 
means (6.5 days) is definitely shorter than treatment period using the surgical-orthopedic methods (12.2 days). Obviously, hospitalization period in the case of midface fractures in great extend depends on the anterior cranial fossa involvment. The selection of treatment method happens after full radiotherapeutic documentation is gathered including CT which allows precisely localize fraction fissures and the extend of bone fraction dislocation and correlation of aquired results with clinical examination and additional examinations $[2,18]$. In our clinic, in the treatment of midface fractures prevails intraoral approach $(69.6 \%)$ which allows for extend operational liberty in the extend of maxillary sinuses as well in zygoma with complimentary cuts in case of necessity of revising orbital walls. In this case more and more intraconjunctival approach is used (8.0\%) in the access to the floor and inferior rim of orbit. The examination gives a better insight into medial and lateral wall of orbit. What is more, it is characterized by a slight blooding, lack of astringent scars and various disfunctions of the lower eye-lid [19].

We will not resign also in reasonable cases from infracilliary or transcutaneous lower-eyelid approach. In the case of necessity of reposition of numerous fractures of upperface region with the necessity of reposition of frontal sinuses walls and revision of anterior cranial fossa, the best choice is to use bicoronal incision [20]. The modified Gillies approach is the golden standard for reposition of zygomatic arch fractures [21].

\section{CONCLUSIONS}

1. In the recent years, an increase in midfacial fractures may be discerned among other types of fractures of maxillofacial area.

2. Early and at the same time stimultaneous team conduct in the treatment of midfacial fractures becomes a standard procedure.

3. Thorough radiologic analysis of injuries using up-to-date research methods allows to establish the most efficient method of therapeutical conduct.

4. An appropriate education, observance of traffic as well as health and safety regulations allows to decrease the number and causes of midfacial injuries.

\section{REFERENCES}

1.Dziadek H, Cieślik T. Leczenie złamań jarzmowo-oczodołowych i jarzmowo-szczękowo-oczodołowych z zastosowaniem repozycji otwartej i bezpośredniej osteosyntezy płytkowej [Treatment of zygomatico-orbital and zygomatico-maxillo-orbital fractures by open reduction and rigid internal fixation]. Wiad Lek. 2005; 58(5-6): 270-274 (in Polish).

2. Eolchiian SA, Potapov AA, Serova NK, Kataev MG, Sergeeva LA, Zakharova NE, Van Damm P. Reonstructive surgery of cranio-orbital injuries. Zh Vopr Neirokhir Im N N Burdenko. 2011; 75(2): 25-39.
3. Stodółkiewicz A. Ocena urazów górnego masywu twarzy i metod leczenia pacjentów Kliniki Chirurgii Stomatologicznej i SzczękowoTwarzowej Akademii Medycznej w Lublinie w latach 1990-1999. Praca doktorska. 2002.

4. Gassner R, Tuli T, Hachl O, Rudisch A, Ulmer H. Cranio-maxillofacial trauma: a 10 year review of 9543 cases with 21067 injuries. J CranioMaxillofacial Surg. 2003; 31: 51-61.

5. Maliska MC, Lima Junior SM, Gil JN. Analysis of 185 maxillofacial fractures in the state of Santa Catarina, Brazil. Braz Oral Res. 2009 Jul-Sep; 23(3): 268-274.

6. Malara P, Malara B, Drugacz J. Characteristics of maxillofacial injuries resulting from road traffic accidents - a 5 year review of the case records from Department of Maxillofacial Surgery In Katowice, Poland. Head Face Med. 2006; 2-27.

7. Dimitroulis G, Eyre J. A 7-year review of maxillofacial trauma in a central London hospital. Br Dent J. 1991 Apr 20; 170(8): 300-2.

8. Wanyura H, Samolczyk-Wanyura D. Grupy kliniczno-anatomopatologiczne złamań górnego masywu twarzy. Złamania odosobnione GMT. Czas Stomatol. 1992; 65(5): 287-293 (in Polish).

9. Mohajerani SH, Ashari S. Pattern of mid-facial fractures In Teheran, Iran. Dent Traumatol. 2011; 27(2): 131-134.

10. Samolczyk-Wanyura D. Epidemiologiczna oraz kliniczno-radiologiczna ocena chorych leczonych z powodu przemieszczeń oczodołowo-nosowych - obserwacje własne [Epidemiologiczna oraz kliniczno-radiologiczna ocena chorych leczonych z powodu przemieszczeń oczodołowo-nosowych - obserwacje własne]. Czas Stomatol. 2005; LVIII(11): 822-829 (in Polish).

11. Szarmach J, Grabowska SZ. Analysis of the maxillofacial fracture model in a 30-year clinical material. Pol J Environ Stud. 2009; 18(1A): 281-286.

12. Samolczyk-Wanyura D. Leczenie chorych z przemieszczeniami górnego masywu twarzy-obserwacje własne [Management of patients with upper face massive dislocation - own observations]. Czas Stomatol. 2006; LIX(10): 711-723 (in Polish).

13. Kapoor P, Kalra N. A retrospective analysis of maxillofacial injuries in patients reporting to a tertiary care hospital in East Dehli. Int J Crit Ill Sci. 2012; 2(1): 6-10.

14. Adeyemo WL, Ladeiende AL, Ogunlewe MO, James O. Trends and characteristic of oral and maxillofacial injuries on Nigeria: a review of the literature. Head Face Med. 2005; 1-7.

15. Chrcanovic BR, Freire-Maia B, Souza LN, Araujo VO, Abreu MH. Facial fractures: a 1-year retrospective study In a hospital In Belo Horizonte. Braz Oral Res. 2004 Oct-Dec; 18 (4): 322-8.

16. Yamamoto K, Matsusue Y, Murakami K, Horita S, Sugiura T, Kirita T. Maxillofacial fractures In older patients. J Oral Maxillofac Surg. 2011; 69(8):B2204-10.

17. Bartoszcze-Tomaszewska M, Tomaszewski T, Woronko P, Stodółkiewicz A, Wojciechowicz J. Epidemiologiczna ocena obrażeń czaszki twarzowej spowodowanych wypadkami przy pracy w regionie lubelskim. [Epidemiological evaluation of trauma to the facial skeleton resulting from accidents at work in the region of Lublin]. Czas Stomatol. 1998; 51(7): 474-478 (in Polish).

18. Lun-Jou Lo, Yu-Ray Chen. Three-Dimensional Computed Tomography Imaging in Craniofacial Surgery: Morphological Study and Clinical Applications. Chang Gung Med J. 2003; 26: 1-11.

19.Zapała J, Bartkowski S, Kuchta K, Pałka P, Moskała M, Kwiatkowski S, Cichoński J. Własne doświadczenia w wielospecjalistycznym zaopatrzeniu chorych z obrażeniami twarzowo-czaszkowymi. Czas Stomatol. 1998; LI: 589-593.

20.Zapała J, Skif F, Moskała M, Krupa M. Wyniki zespołowego leczenia obrażeń zatok czołowych. Neurol Neurochirurg Pol. 2006; 40(5): 376-385.

21. Swanson E, Vercler C, Yaremchuk MJ, Gordon CR. Modified Gillies approach for zygomatic arch fracture reduction in the setting of bicoronal exposure. J Craniofac Surg. 2012; 23(3): 859-862. 